بررسى آلودگى زيستمحيطى رسوبات آبراههاى به عناصر سنخين در منطقه

زرشوران- آغدره (شمال تكاب)

سيده بريسا موسوى'، ميرعلى اصغر مختارى"، يونس خسروى "، على رفيعى"، رضا حسينزاده

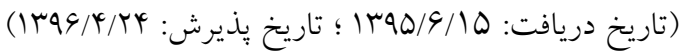

جكيده

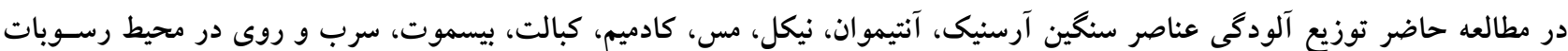

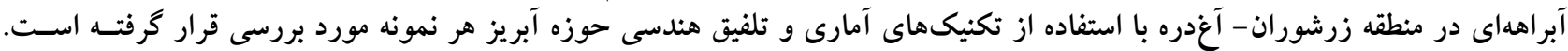

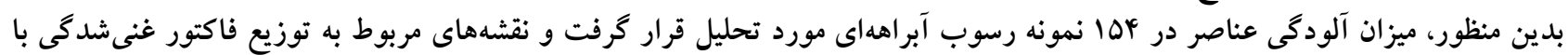

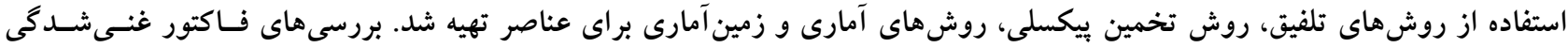

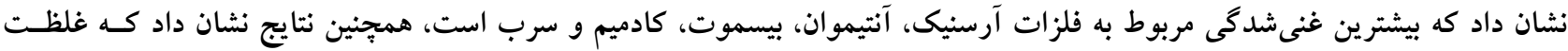

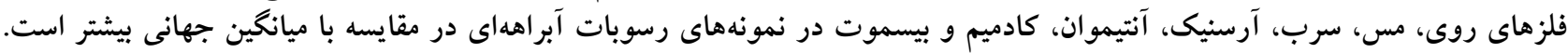

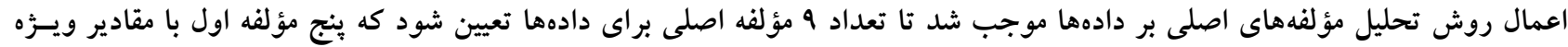

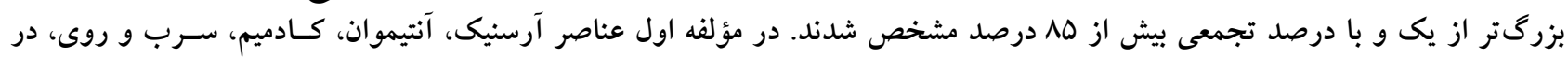

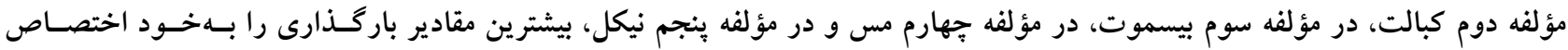

دادهاند.

وازههاى كليدى: عناصر سنخين، آلودگى زيستمحيطى، فاكتور غنىشدگى، تحليل مؤلفهاى اصلى، زرشوران، آغدره، تكاب

1. كروه علوم محيط زيست، دانشكده علوم، دانشخاه زنجان

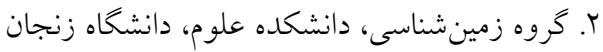
r. كَروه مهندسى معدن، دانشكده مهندسى، دانشكاه زنجان ع أ. سازمان زمينشناسى و اكتشافات معدنى كشور، تهران

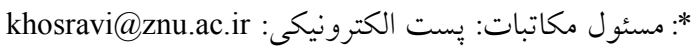


وضعيت زمينشناسى و فعاليتهاى معلنى در منطقه زرشورانمقدمه

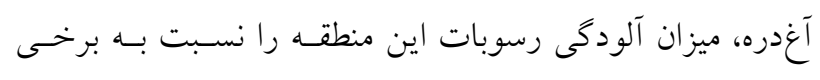

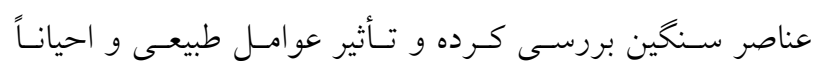
انسانى در ايجاد آلودگى تعيين شود. بردئ

\section{مواد و روشها معرفى منطقه مورد مطالعه} منطقه زرشوران- آغذره در شمال تكاب واقع بوده و در فاصـله

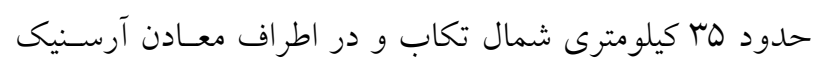

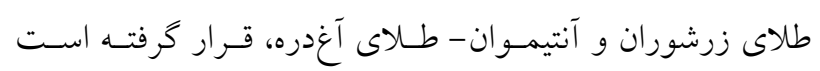

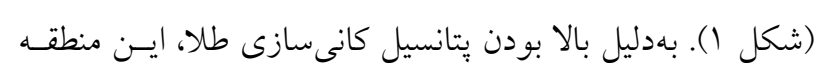

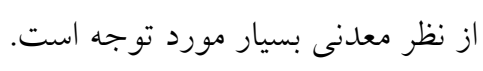

زمينشناسى منطقه مورد مطالعه

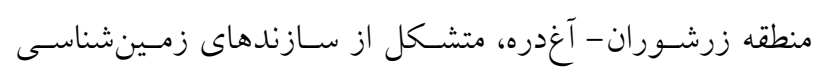

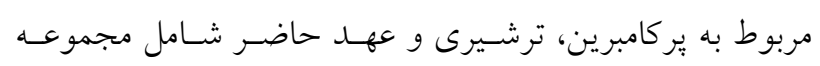

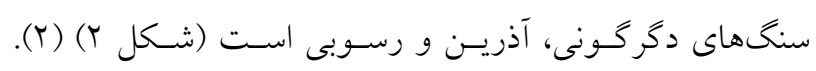

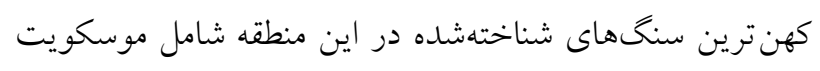

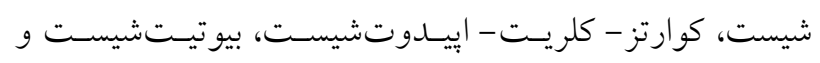

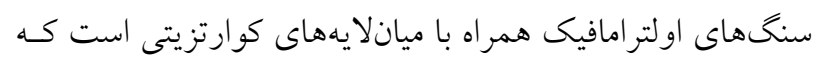
در زير آهك و دولوميتهاى مرمرى شـده (مرمـر جانكو تـاران)

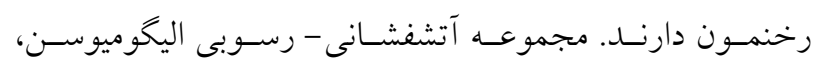

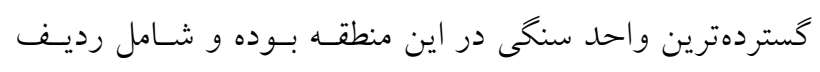

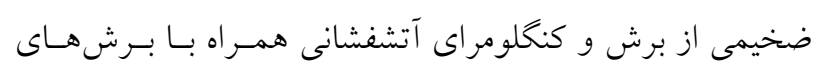

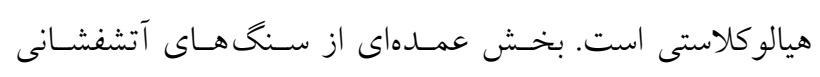

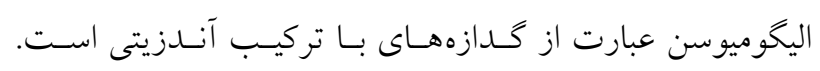

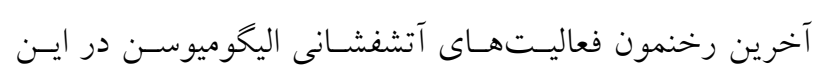

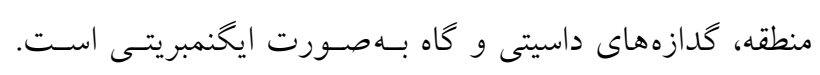

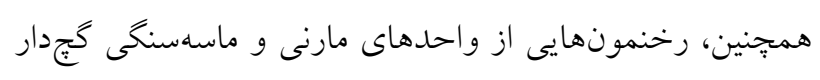

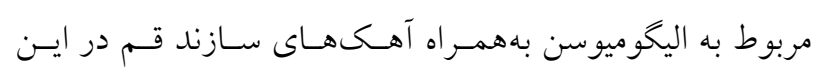

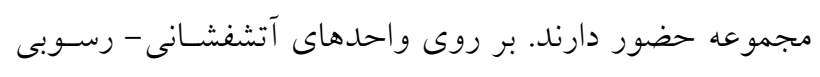

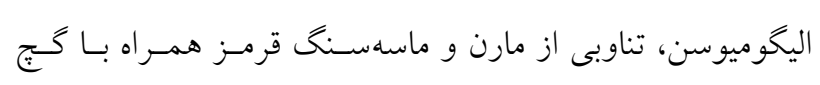

تخريب و آلودكى محيط زيست، ثمره جوامع صنعتى و يكى از

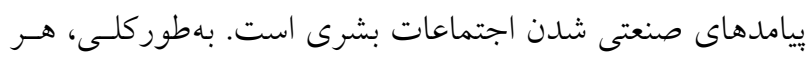

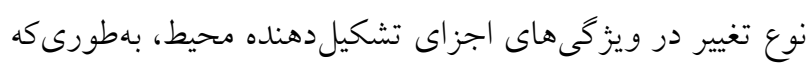
عملكرد طبيعى و تعادل زيستى آنها مختل شود و بهطور مستقيم

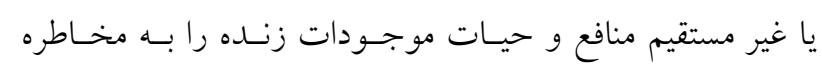

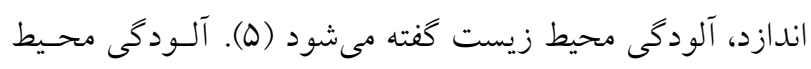

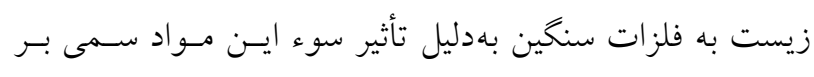

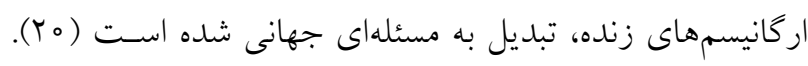

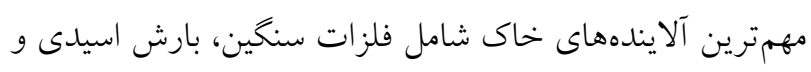

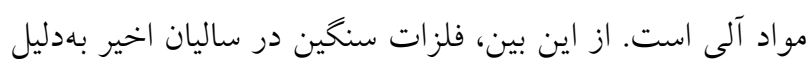

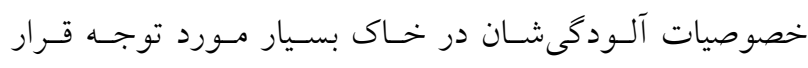

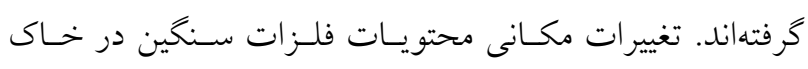
سطحى كشاورزى ممكن است تحت تأثير مواد خاك مـادرى و

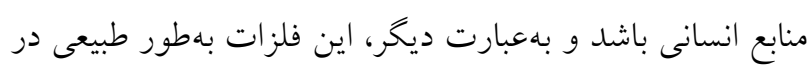

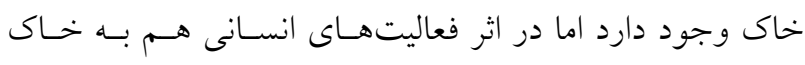

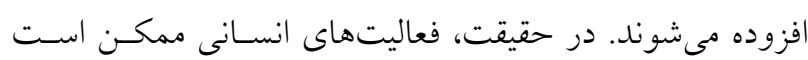

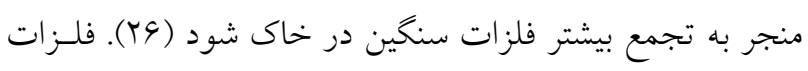

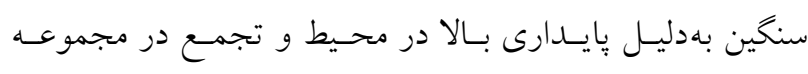

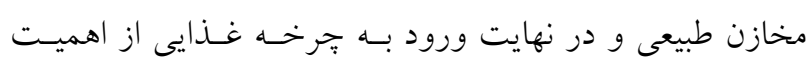

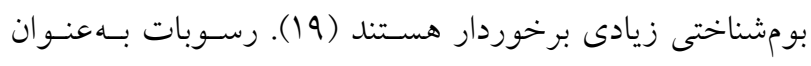

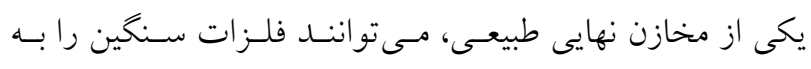

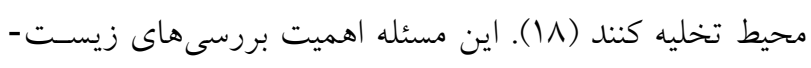

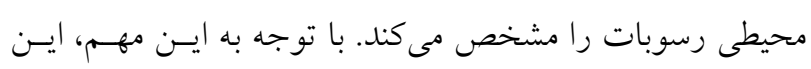

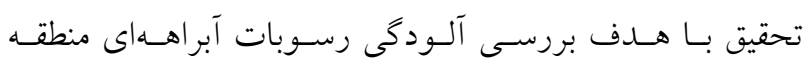

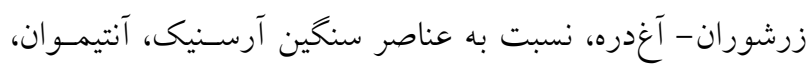

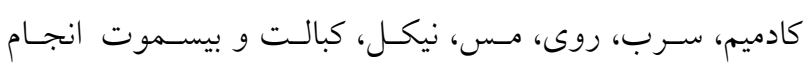

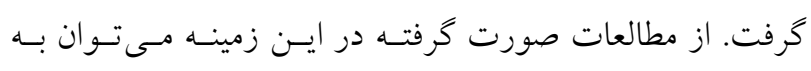

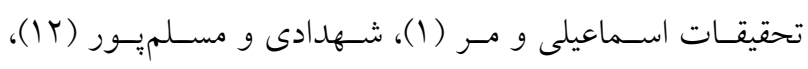

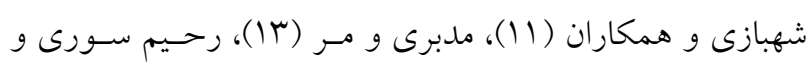

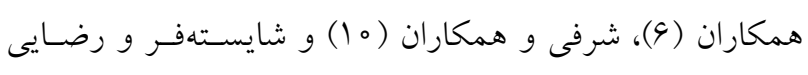

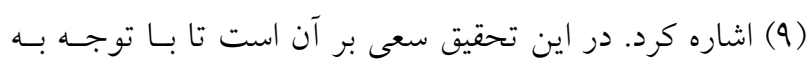




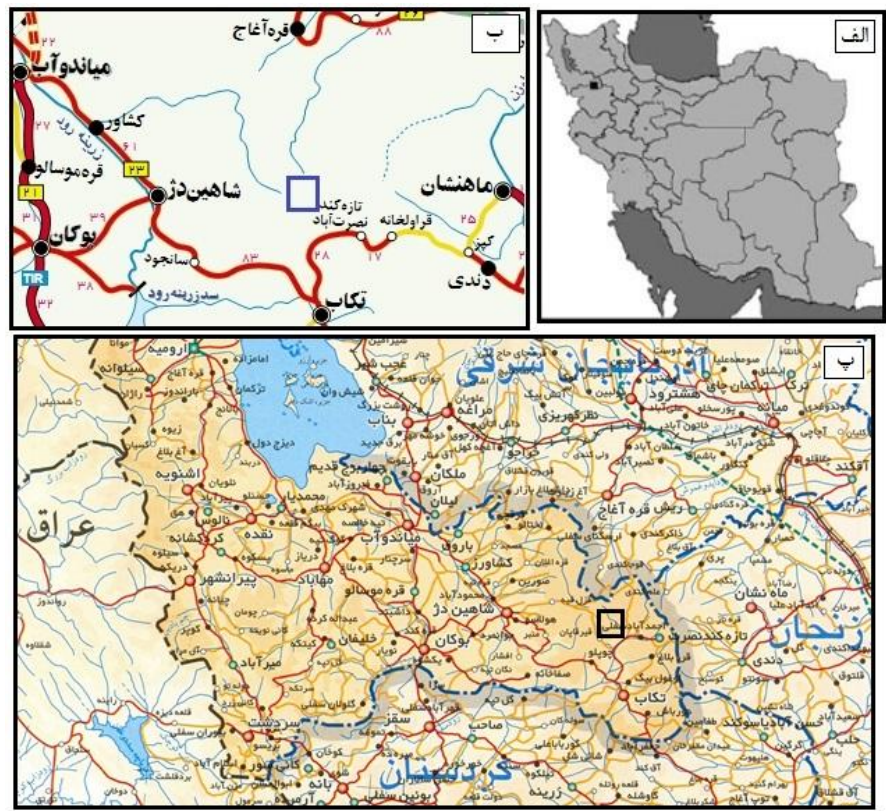

شكل ا. الف) موقعيت منطقه مورد مطالعه در شمال غرب ايران و در استان آذربايجان غربى، ب) موقعيت منطقه مورد مطالعه در شمال تكاب و راههاى دسترسى به آن و ب) موقعيت منطقه مورد مطالعه در استان آذربايجان غربى و شمال تكاب
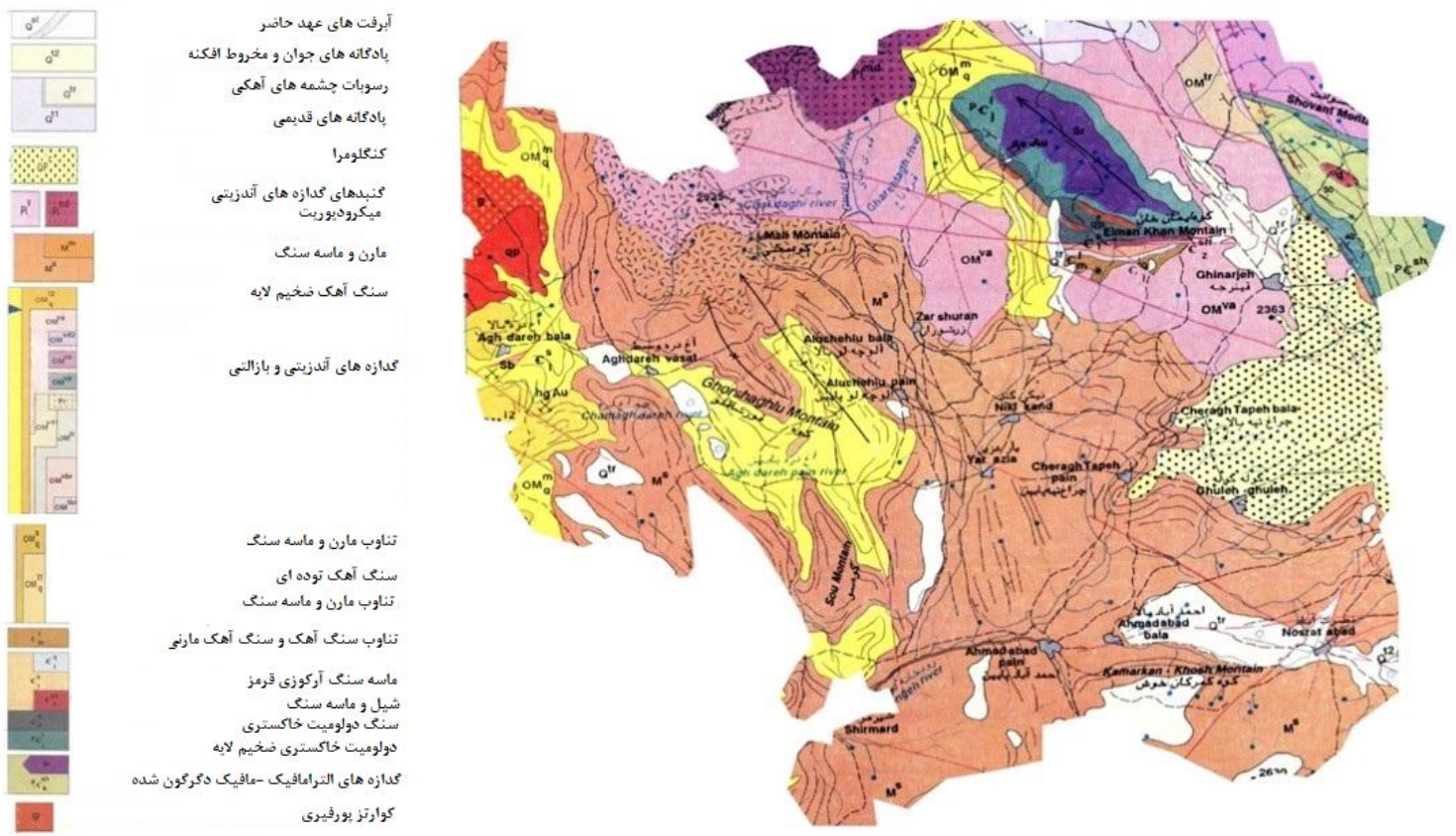

شكل Y. نقشه زمينشناسى محدوده مورد مطالعه براساس نقشه زمين شناسى 00 00 1:1 ا تخت سليمان (Y)

در بخشهاى غربى منطقه نيز گرانيت آغدره قابل مشاهده است.

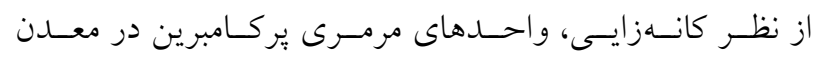

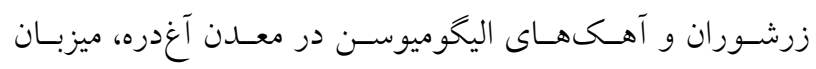
كانىزايى آرسنيك، آنتيموان و طلا هستند.
(رسوبات سازند قرمز بالايى) بهطور ناهمشيب قرار گر فته است.

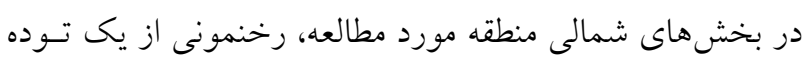

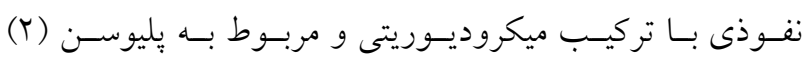
رخنمون دارد كه واحدهاى سنكى ميزبان را دكرسان كرده است. 


\section{بردازشهاى آمارى} بس از دريافت نتايج آناليز شيميايى نمونهها، بهمنظور بردازش و تحليـل آمــارى دادههــا و بررسـى نرمــال بــودن دادههــا، از

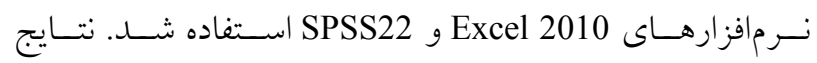
بهدست آمده مربوط بـه بــردازش بارامترهـاى آمـارى ميـانخين، ميانه، مد، انحراف معيار، جورلكى و كشـيدگى، دامنـه، حــداقل و حداكثر غلظت براى 9 عنصـر در جــدول (1) نشـان داده شـده

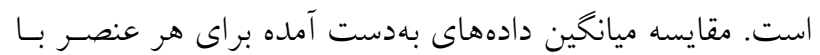

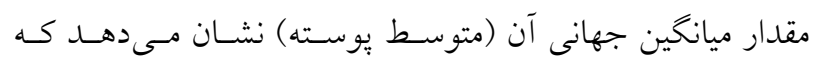
نمونههـاى رسـوب آبراهـهاى در منطقـه مـورد مطالعـه از نظـر

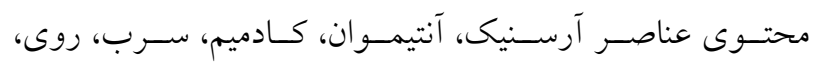
بيسموت و مس بيشتر از ميانكين يوسته و مقدار نيكل و كبالـت كمتر از ميانخين بوسته است (جدول (1).

\section{مطالعات آمارى تكمتغيره}

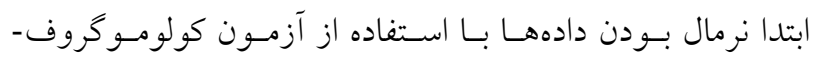
اسميرنوف مورد بررسى قرار گرفت و سـيس مطالعـات آمـارى تكىمتغيره (محاسبه مشخصههاى آمارى) و مطالعات آمارى جنيد

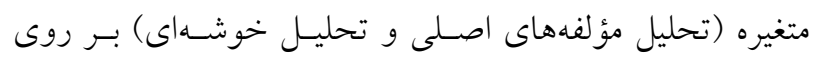

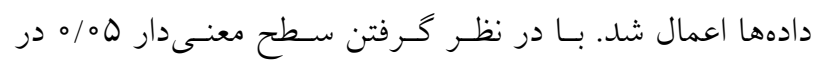

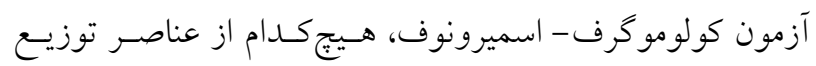
نرمال نداشته (جدول Y) و نياز است قبـل از هركونسه :هردازش

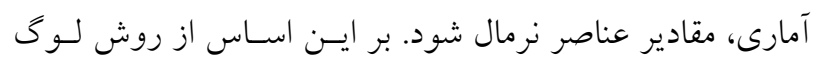
نرمال براى نرمالسازى توزيع دادههاى خام غير نرمـال اسـتفاده شد. روش لو

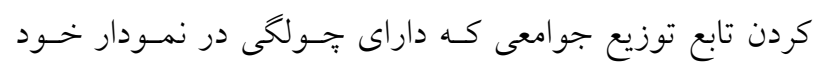

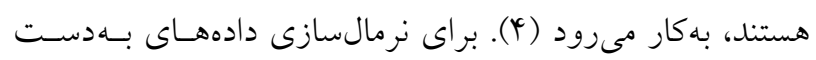

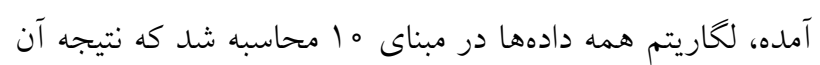
در جدول (r) نشان داده شده است. هيستو گرام توزيـع مقـادير لو ع عناصر آرسنيك، آنتيموان، كادميم، كبالـت، سـرب، نيكـل،
در مرحله اول موقعيت نمونههاى مورد نظر با توجه به وضعيت

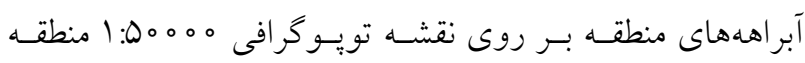

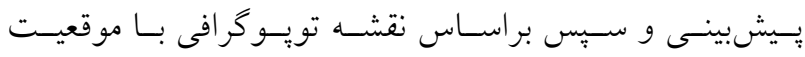
نمونهاى از بيش تعيين شده و دستخاه موقعيتياب جغرافيـايى

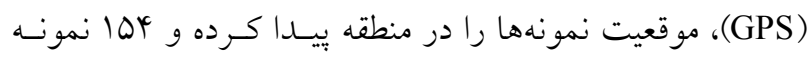

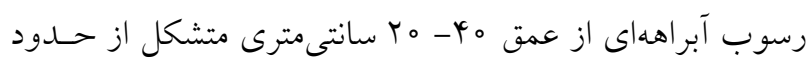

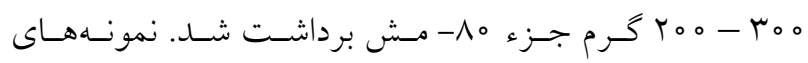

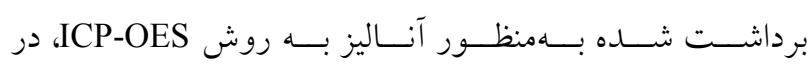
آزمايشخاههاى سازمان زمينشناسى و اكتشـافات معـدنى كشــور

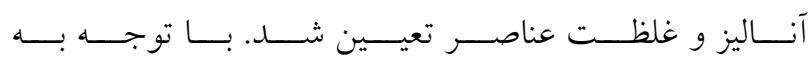

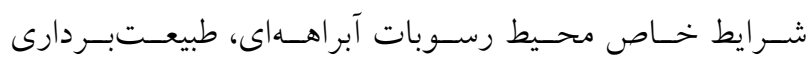
آن را در تحليـلهـــا مــنظظر قــرار داده و سـعى شــد مقــادير

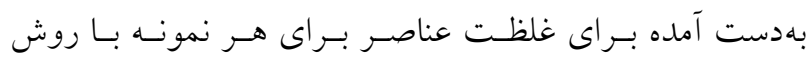

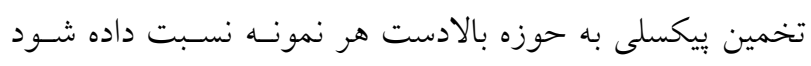

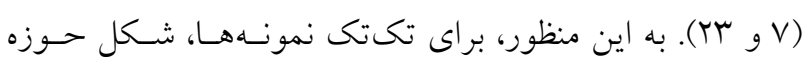

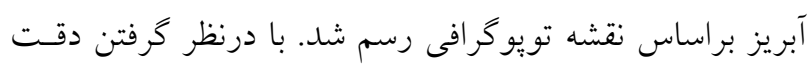

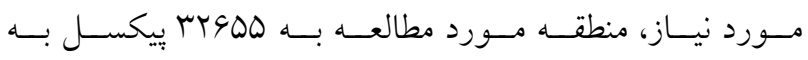
ابعاد ه ه ×× ها متر تقسيم شد. هر بيكسل براسـاس قرارگيـرى

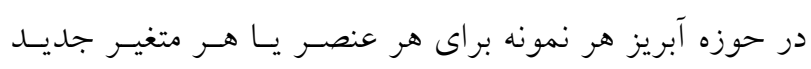

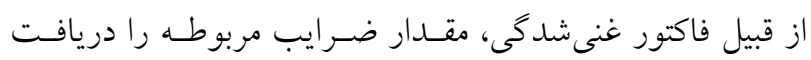
كرد و در نهايت، تعداد مقادير كه در ابتدا براى ها المونه بـوده

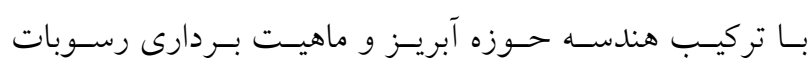

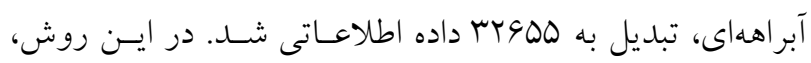

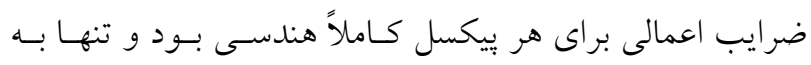

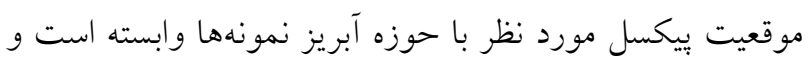
صرفاً جهت درنظر كرفتن توزيعبردارى غلظت عناصر در محيط آبراههاى است. اين روش، نقاط ضعف موجـود در روشهـايى

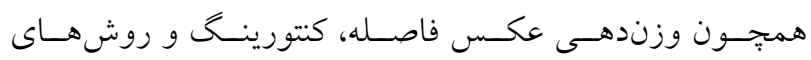

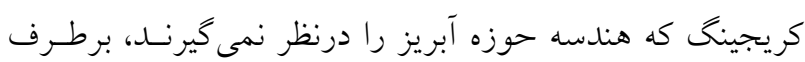
مى كند، همجينين، در مراحل بعد قابليت تلفيق با اين روشهـا را

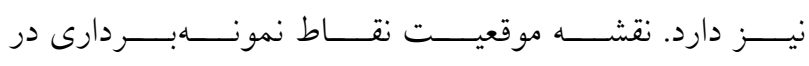



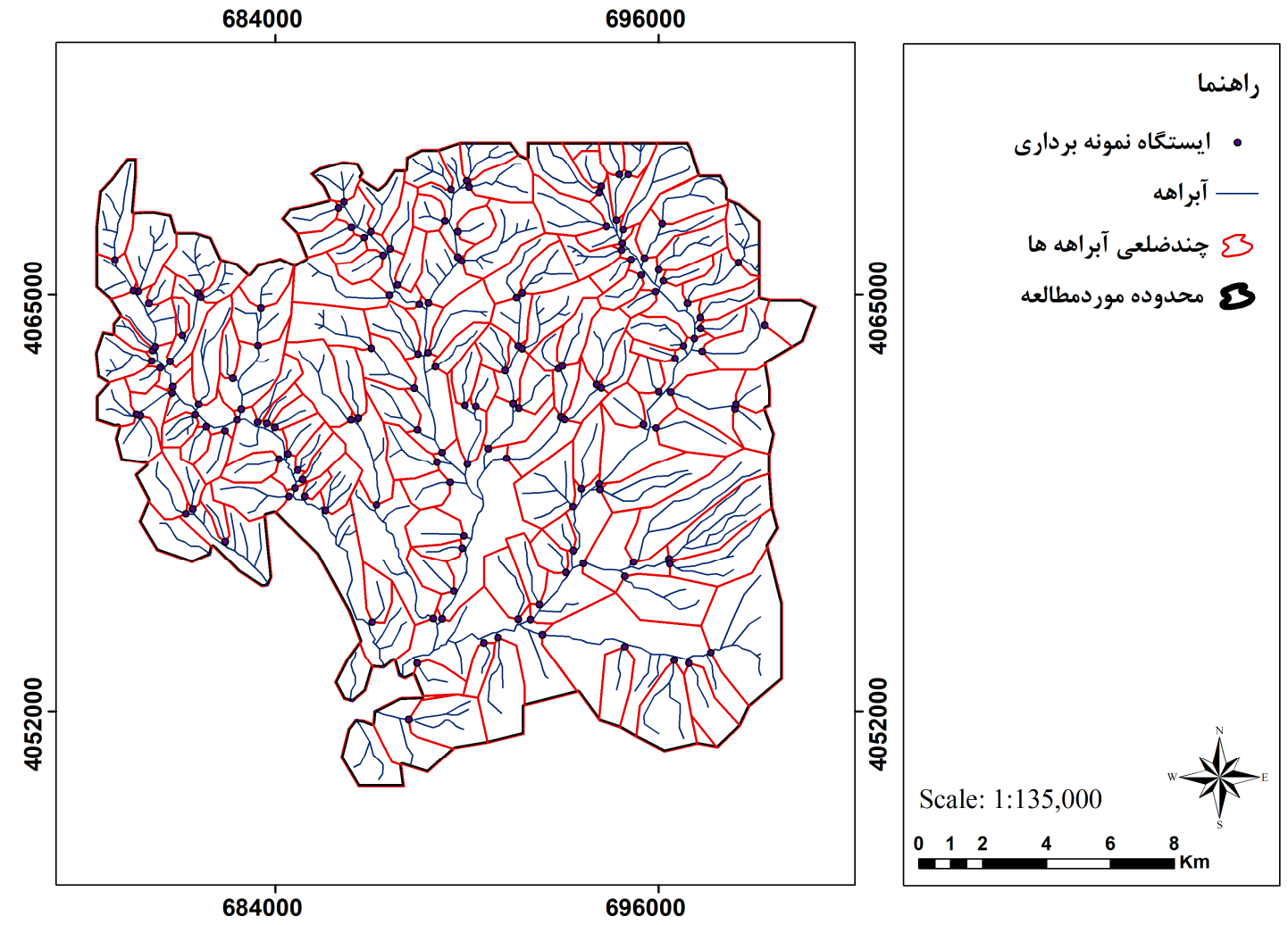

شكل r. نقشه موقعيت نقاط نمونهبردارى در محدوده مورد مطالعه بههمراه جِند ضلعىهاى مربوط به حوزه آبريز هر نمونه

جدول ا. بارامترهاى آمارى محاسبه شده براى عناصر آناليز شده در منطقه مورد مطالعه

\begin{tabular}{|c|c|c|c|c|c|c|c|c|c|}
\hline آرسنيك & آنتيموان & بيسموت & كادميم & كبالت & سرب & نيكل & مس & روى & عناصر سنگين \\
\hline lor & 104 & 104 & lQY & $10 \%$ & 104 & $10 \%$ & 104 & $10 F$ & تعلداد نمونه \\
\hline 149 & $r Y / 0 D$ & $0 / 49$ & $0 / 99$ & $10 / N \pi$ & $v 0 / 19$ & $0 . / 1 V$ & $\mu \circ / \mu$ & $1 V \circ / r q$ & "ميانخين \\
\hline$\Delta \Delta$ & r & $\circ \mu$ & $\circ / 4 V$ & $1 Y / 9 T$ & TN/AT & $r T / 4 q$ & $r Y / 99$ & $94 / 49$ & ميانه \\
\hline 10 & $1 / 0$ & $\circ \pi$ & $\circ / 0 \wedge$ & $r / 4$ & $\Delta / r$ & N/GY & $V / D$ & Tr/GV & مد (نما) \\
\hline$r \Delta Q / \circ \wedge$ & $V 4 / 19$ & $\circ / N$ & $r / Q Y$ & $V / r$ & $110 / 00$ & $119 / 91$ & $r \mu / N$ & TET/OT & انحراف از معيار \\
\hline IrAQTV/4 & $\Delta Q \circ 4 / \pi T$ & $\circ / \Delta r$ & $9 / 4 \mathrm{~V}$ & $\Delta r / \pi r$ & $1 \pi T \omega \cdot N{ }^{4}$ & IYGAY/IV & $\Delta Q T / T q$ & ITIKTIGK & واريانس \\
\hline V/Va & $9 / \pi \Lambda$ & $4 / 9 \mathrm{~V}$ & $9 / \Delta D$ & $r / 09$ & $r / M r$ & $10 / V 9$ & $\Delta / T \Delta$ & $9 / \pi \wedge$ & جولكى \\
\hline$V \pi / 14$ & 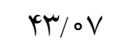 & $T Y / Y G$ & $104 / V A$ & $T Q / G T$ & $r Y / \wedge q$ & $\mid T Q / T Q$ & rNNT & $101 / 14$ & كشيدگى \\
\hline rvar & $9 \circ 9 / \Delta 0$ & $\Delta / \varphi$ & $r q / 44$ & $V 0 / 01$ & $914 / 9 V$ & $|Y| T / O V$ & TrV/OV & $Y|V T / q|$ & دامنه \\
\hline v & $\circ / 4 \Delta$ & $\circ / 1$ & $\circ / \circ \wedge$ & $r / r q$ & $\Delta / \pi$ & N/GY & $V / Q$ & $r T / G V$ & حداقل \\
\hline rへ。o & 910 & $Q / D$ & $r q / Q 1$ & $V \Psi / q$ & $9 r_{0}$ & $14 T \circ / 99$ & $r r \Delta / \circ V$ & $4190 / \Delta \wedge$ & حداكثر \\
\hline I/V & $\circ / r$ & $\% / \wedge \Delta$ & $\circ / 1$ & YY & $1 \% / 1$ & QS & ro & 90 & ميانخين بوسته \\
\hline
\end{tabular}


جدول r. آزمون كولموگروف- اسميرنوف براى بررسى توزيع نرمال دادههاى عناصر سنخين مورد مطالعه در رسوبات آبراههاى

\begin{tabular}{|c|c|c|c|c|c|c|c|c|c|c|}
\hline آرسنيك & آنتيموان & بيسموت & كادميم & كبالت & سرب & نيكل & مس & روى & \multicolumn{2}{|c|}{ عناصر سنخين } \\
\hline 104 & $10 \%$ & $\left.10\right|^{4}$ & lor & 104 & $10 \%$ & lQY & 104 & 104 & \multicolumn{2}{|c|}{ تعداد نمونه } \\
\hline 179 & $r Y / \circ D$ & $0 / 49$ & $0 / 99$ & $10 / N \pi$ & $V 0 / 19$ & $0 . / I V$ & $\mu \circ / \mu$ & $1 V 0 / \pi q$ & ميانكين & بار امترهاى \\
\hline$r \Delta q / \circ \wedge$ & $V 4 / 19$ & $\circ / N$ & $r / Q Y$ & $V / \mu$ & $110 / \Delta \Delta$ & $119 / 91$ & $r \mu / N$ & TGY/OT & انحر اف از معيار & نرمال او r \\
\hline $0 / 44$ & $0 / \pi q$ & $\circ / \pi$ & $0 / 49$ & $0 / 1 Y$ & $0 / 7 q$ & $0 / M^{\prime}$ & $\circ / T \Delta$ & $0 / \mu r$ & مطلق & \\
\hline $0 / \pi 1$ & $0 / \mu r$ & $0 / \pi$ & $\mu_{0}$ & $0 / M r$ & $\circ / \Gamma \wedge$ & $0 / r 4$ & $0 / T \Delta$ & Tr & مثبت & \\
\hline$-0 / 44$ & $-0 / \pi 9$ & $-\circ / r$ & $-0 / r_{4}$ & $-0 / 09$ & $-0 / 79$ & $-0 / 49$ & $-0 / 19$ & $-0 / \mu r$ & منفى & \\
\hline $0 / \pi q$ & $0 / \pi q$ & 每 & $0 /{ }^{\prime}$ & $0 / 1 Y$ & $0 / r q$ & $0 / r 4$ & $\circ / T \Delta$ & $\circ / \mu K$ & 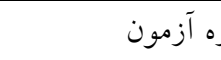 & \\
\hline$\circ / \circ \circ \circ \mathrm{C}$ & $\circ / 0 \circ \circ \mathrm{c}$ & $\circ \% \circ \circ \mathrm{c}$ & $\circ / \circ \circ \circ \mathrm{c}$ & $\circ / \circ \circ \circ \mathrm{C}$ & $\circ / 0 \circ \circ \mathrm{c}$ & $\circ / \circ \circ \circ \mathrm{c}$ & $\% \circ \circ \circ \mathrm{C}$ & $\circ / \circ \circ \circ \mathrm{c}$ & Asymp. Sig. & (2-tailed) \\
\hline
\end{tabular}

جدول r. يارامترهاى محاسبه شده براى مقادير لوگ عناصر مورد مطالعه

\begin{tabular}{|c|c|c|c|c|c|c|c|c|c|}
\hline آرسنيك & آنتيموان & بيسموت & كادميم & كبالت & سرب & نيكل & مس & روى & عناصر سنخين \\
\hline 104 & 104 & $10)^{4}$ & lor & 104 & $10 \%$ & 104 & lor & 104 & تعداد \\
\hline $1 / N V$ & $0 / 91$ & $-0 / \uparrow \wedge$ & $-0 / 79$ & $1 / 19$ & $1 / 0 \Lambda$ & $1 / \Delta t$ & $1 / 4 T$ & $r / 0 \Delta$ & ميانخين \\
\hline $1 / V^{4}$ & $0 / 4 \wedge$ & $-0 / 0 T$ & $-0 / \pi r$ & $1 / 1 V$ & $1 / 49$ & $1 / 01$ & $1 / \pi q$ &.$/ 91$ & ميانه \\
\hline $1 / 11$ & $\circ / 1 \Lambda$ & - o/Qr & $-1 / 1 r$ & $\circ / \Delta r$ & $\circ / N$ &.$/ 94$ & $\circ / M$ & $1 / r^{4}$ & مد (نما) \\
\hline.$/ 01$ & $0 / 9 \mathrm{~V}$ & $0 / 1$ & $0 / 4 T$ & $\circ / 1 \Lambda$ & D & $0 / T \Lambda$ & $0 / r 1$ & $0 / 1$ & انحراف از معيار \\
\hline $0 / T 9$ & $0 / 4 \Delta$ & $\circ / 1$ &.$/ 1$ & $\circ /{ }^{\prime}$ &.$/ 11$ & $\circ / 1$ &.$/ 0 \Delta$ & $0 / 1$ & واريانس \\
\hline$\circ / \Delta r$ & $\circ / \sqrt{ } q$ & $1 / 4 V$ & $\circ / \Lambda 1$ & $-0 / 10$ & $0 / 99$ & $1 / N$ & $\circ / 91$ & $1 / 09$ & جولنى \\
\hline$\circ / 09$ & $0 / r \mu$ & $r / 10$ & $1 / 41$ & $1 / 19$ & $0 / 91$ & $V / \Delta D$ & r/Ar & $Y / V V$ & كشيدكى \\
\hline$r / N$ & $\mu / \mu$ & $\circ / N F$ & $r / Q 9$ & $1 / \pi r$ & $T / T Y$ & T/TY & $1 / 0$ & $T / T V$ & دامنه \\
\hline$\circ / \wedge \Delta$ & -o/r山 & -1 & $-1 / 1 r$ & •/Or & $\circ / N r$ &.$/ 94$ & $\circ / M$ & $1 / \pi 4$ & حداقل \\
\hline$r / \Delta \Lambda$ & T/Vq & $\circ N^{4}$ & $1 / 4 V$ & $1 / A V$ & T/99 & $r / 10$ & $r / T V$ & r/9T & حداكثر \\
\hline
\end{tabular}

آرسنيك در دو حالت خام و نرمال شده نشـان داده شــه اسـت (شكل ه) (شن)

مطالعات آمارى جند متغيره بررسى همبستخى عناصر مورد مطالعه

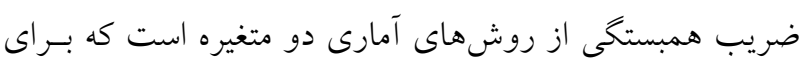

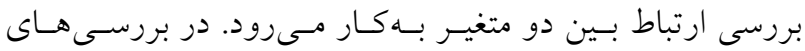
زُئوشيميايى، بعضى از عناصـر نسـبت بـه يـك سـرى شـرايط
مس و روى جــولكى نداشـته و داراى توزيـع نرمـال و متقــارن

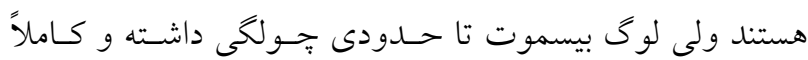

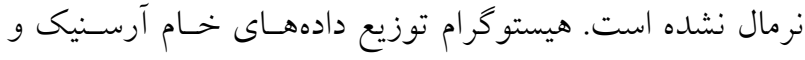

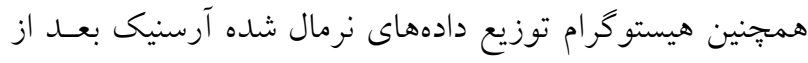

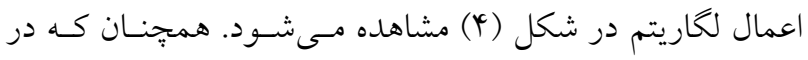

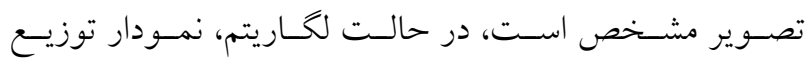

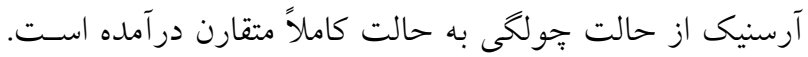

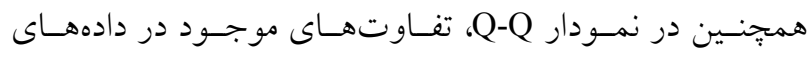



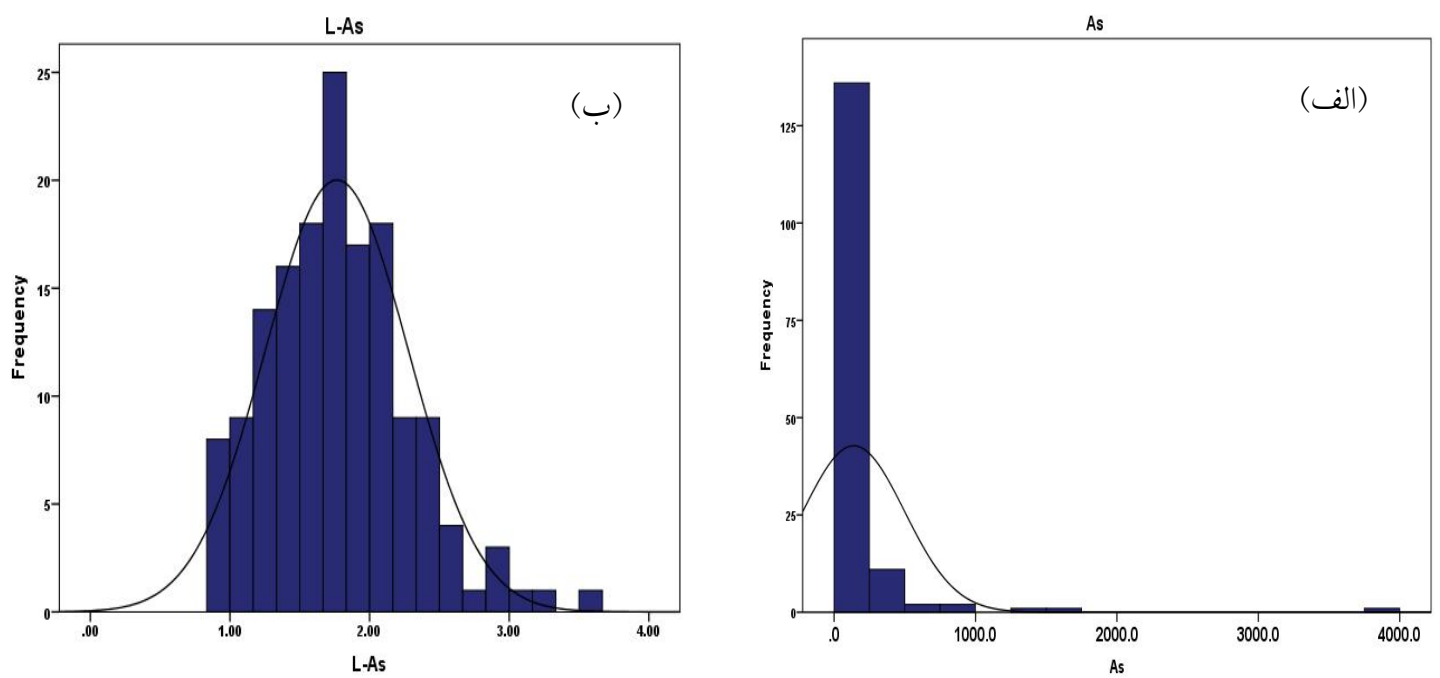

شكل f. الف) هيستوگرام توزيع دادههاى خام آرسنيك و ب) هيستوگرام توزيع دادههاى نرمال شده آرسنيك
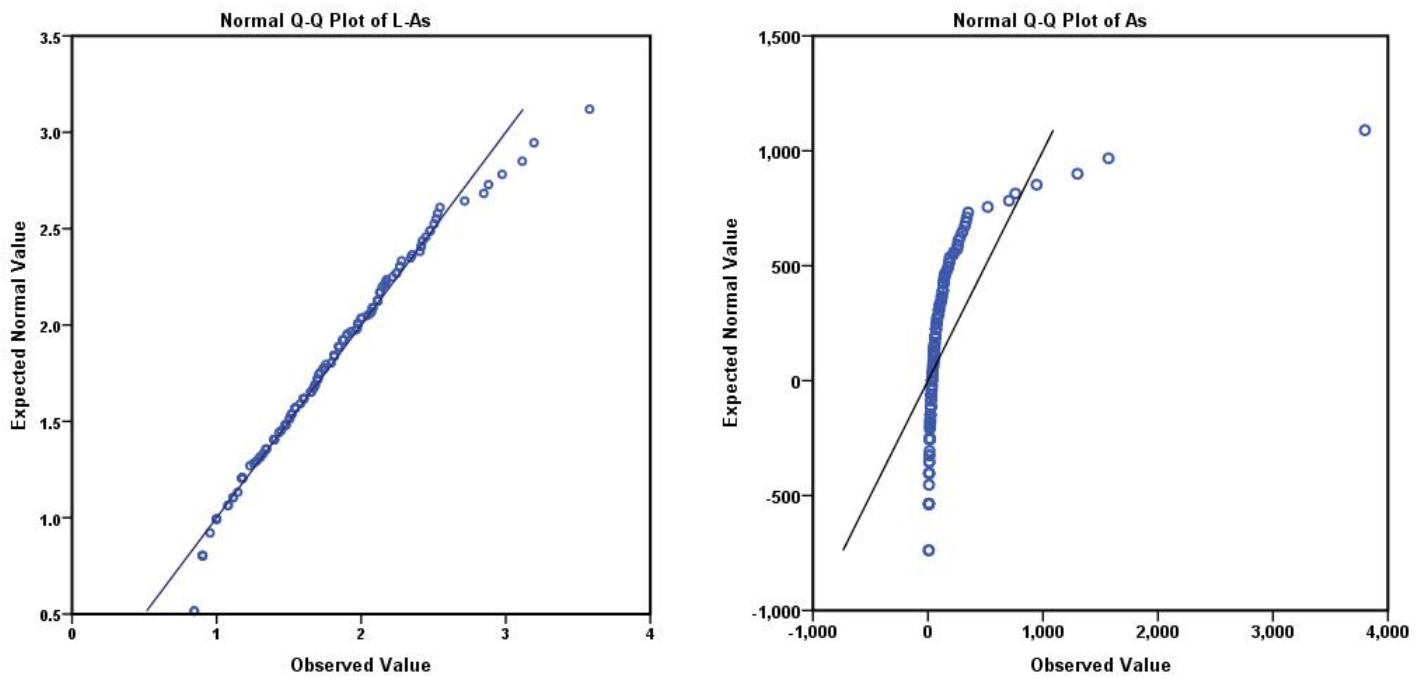

شكل ه. الف) نمودار Q-Q يلات دادههاى خام آرسنيك و ب) نمودار Q-Q يلات دادهاى نرمال شده آرسنيك

همبستخى بسيار قوى با كادميم و آنتيموان و همبستكى قـوى بـا سرب و روى نشان مىدهد. همجنين، آنتيموان داراى همبستخى بسيار قوى با كادميم و همبستكى قوى بـا سـرب و روى روى اسـت. كادميم همبستخى بسيار قوى با روى و همبستخى قوى با سـرب

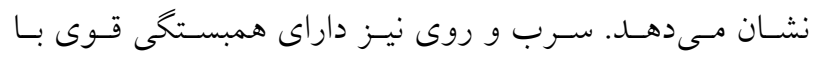
يكديخر هسـتند. كبالـت و نيكـل داراى همبسـتخى متوسط بـا يكديخر بوده و مس و بيسموت نيز داراى همبستخى قوى با هم

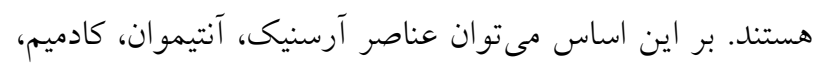

محيطى رفتار مشابهى دارند كه مسىتـوان آنها را در علـتهـاى تقريباً واحد جستجو كرد. با شناخت ارتباط بين عناصر مىتـوان به درى اين شرايط، تفسـير محسيطهـاى زئوشـيميايى، شـناخت كانهزايىهاى احتمالى و در نهايت شناخت مناطق آنومال دسـت يافت (Y). به اين منظور، همبستكى بـين عناصـر مـورد مطالعـه براى مقادير لوى عناصر محاسبه شد كه نتايج آن در جدول (Y) نشان داده شده است. همجِنان كه در جدول (Y) مشخص است، عنصـر آرسـيك 


\begin{tabular}{|c|c|c|c|c|c|c|c|c|c|}
\hline روى & مس & نيكل & سرب & كبالت & كادميم & بيسموت & آنتيموان & آرسنيك & \\
\hline & & & & & & & & 1 & آرسنيك \\
\hline & & & & & & & 1 & O/AY & آنتيموان \\
\hline & & & & & & 1 & $0 / 140$ & $0 / M G$ & بيسموت \\
\hline & & & & & 1 & $0 / 49$ & $\circ / \wedge 1$ & $\circ / \wedge \Delta$ & كادميم \\
\hline & & & & 1 & $\circ / \Upsilon \wedge$ & $0 / 10$ & $0 / 01$ & $0 / 19$ & كبالت \\
\hline & & & 1 & س & $\circ / V \wedge$ & $0 / 91$ & $\circ / V 4$ & $0 / 99$ & سرب \\
\hline & & 1 & $o / 4 y$ & $\circ / D Y$ & $\circ / 0 \circ$ & $0 / 14$ & $0 / Y q$ & O/MY & نيكل \\
\hline & 1 & $\circ / M V$ & $\circ / 0 \circ$ & $0 / \mu 1$ & R & $0 / 9 \mathrm{~V}$ & $0 / 49$ & $\circ / \mu$ & مس \\
\hline 1 & $0 / 41$ & $\circ / D T^{r}$ & $\circ / V Q$ & $\circ / \Delta \Delta$ & -/AY & $0 / 4 q$ & $0 / 99$ & $0 / 99$ & روى \\
\hline
\end{tabular}

جدول ه. نتايج حاصل از اعمال روش تحليل مؤلفهاى اصلى بر دادهها

\begin{tabular}{|c|c|c|c|c|c|c|}
\hline \multicolumn{3}{|c|}{ جرخش در مؤلفههاى اصلى } & \multicolumn{3}{|c|}{ مقادير ويزه } & \multirow[b]{2}{*}{ 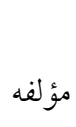 } \\
\hline كل & واريانس (درصد) & درصد تجمعى & كل & واريانس (درصد) & درصد تجمعى & \\
\hline T/Tr & rD/vT & $r \Delta / v Y$ & $0 / 09$ & $\Delta S / D Y$ & $\Delta G / \Delta Y$ & 1 \\
\hline $1 / T Y$ & 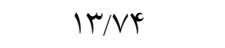 & $4 q / 49$ & $1 / \pi V$ & $1 Q / T V$ & $V \backslash / \Lambda)$ & r \\
\hline I/T & $\mid r / 4 T$ & $91 / 90$ & $1 / 10$ & IT/Vq & $14 / 91$ & r \\
\hline $1 / \circ \wedge$ & $\mid r / 0 Y$ & $\sqrt{ } / 91$ & $\circ / 0$ & $\Delta / \Delta Y^{r}$ & $90 / 14$ & 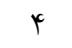 \\
\hline $1 / \circ \wedge$ & ir & $\Lambda \Delta / q T$ & $0 / Y q$ & $r / r V$ & $Q M / 4 T$ & 0 \\
\hline$\circ / \Delta \Delta$ & $9 / 09$ & $9 r / 01$ & س & $T / Q V$ & $90 / 99$ & 9 \\
\hline 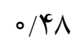 & $\Delta / T q$ & $q V / T_{0}$ & $\circ / 1 \wedge$ & $1 / 99$ & $9 V / 91$ & V \\
\hline - & $|/ 4|$ & QN/VT &.$/ 11$ & $1 / \pi r$ & $99 / 71$ & $\wedge$ \\
\hline $0 / 14$ & $1 / T \Lambda$ & 100 & $\circ / \circ \mathrm{V}$ & $\circ / \mathrm{Vq}$ & 100 & 9 \\
\hline
\end{tabular}

جرخش در مؤلفههاى اصلى، بنج مؤلفه با مقادير ويزه بزرگتـر

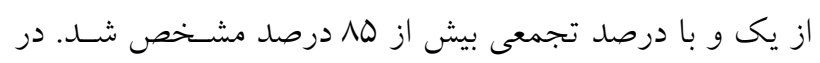
مؤلفه اول عناصر آرسنيك، آنتيموان، كادميم، سـرب و روى، در

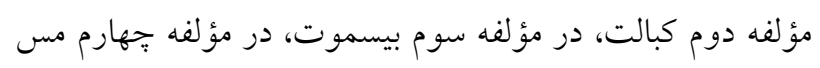

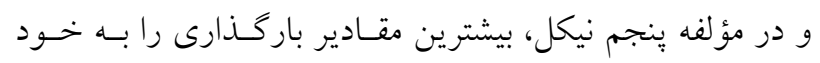

$$
\text { اختصاص دادهاند (جدول 9). }
$$

$$
\text { تحليل خوشهاى }
$$

مطالعات زئوشيميايى رسوبات آبراهـاى مسى توانــ خـام مـؤثرى
سرب و روى را در يك گروه، مس و بيسموت را در يك گـروه و كبالت و نيكل را در كـروه سـوم دسـتهبنـدى كـرد كـه داراى ارتباط زايشى مشابهى هستند.

\section{تحليل مؤلفههاى اصلى}

اعمال روش تحليل مؤلفههاى اصلى موجب شـــ تـا تعـداد نـهـ مؤلفه اصلى مشخص شود كه سـه مؤلفـه اصسلى داراى مقـادير

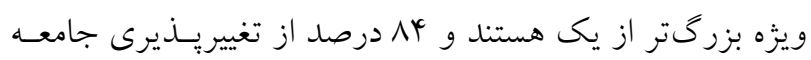

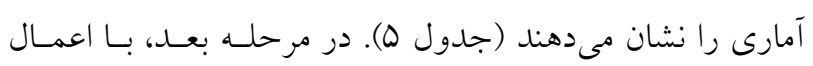


جدول 9. مؤلفها و بار عاملى عناصر در حالت جرخش

\begin{tabular}{|c|c|c|c|c|c|c|c|c|c|}
\hline 9 & $\wedge$ & V & 9 & 0 & r & r & r & 1 & \\
\hline$-0 / Y_{0}$ & $-\circ / \circ \Delta$ & $0 / 01$ & 0109 & $\circ / \Lambda$ & $\circ / 10$ & $0 / 09$ & $0 / 10$ & $0 / 90$ & آرسنيك \\
\hline$\circ / T V$ & $-0 / \circ 0$ & $\circ / 10$ & $\circ / \Lambda$ & $\circ / 00$ & $\circ / T \Delta$ & $0 / Y_{1}$ & $-\circ / \circ \wedge$ & $0 / 91$ & آنتيموان \\
\hline $0 / 01$ & $0 / 0 Y$ & $\circ / \circ \Delta$ & س & $\%$ & . & $0 / 19$ & $\circ / 00$ & $\circ / T \Delta$ & بيسموت \\
\hline$-0 / 0 Y$ & 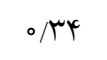 & $0 / T V$ & $0 / 10$ & $O / Y Y$ & $\circ / 1 \wedge$ & $\circ / \Lambda$ & $0 / 1 Y$ & $\circ / \Lambda 1$ & كادميم \\
\hline$-0 / 01$ & $0 / 01$ & $0 / 09$ & $\circ / \circ \mathrm{V}$ & $0 / T \Delta$ & $0 / 11$ & $\circ / 00$ &.$/ 90$ & $0 / 04$ & كبالت \\
\hline $0 / 01$ & $\%$ & $0 / 10$ & $0 / 90$ & $\circ / \wedge$ & $\circ / Y_{0}$ & س & $\circ / \Lambda$ & $0 / 09$ & سرب \\
\hline$\circ / 00$ & $0 / 0 Y$ & $\circ / 0 \wedge$ & $\circ / 0 \wedge$ & $0 / 91$ & $0 / 10$ & $0 / 01$ & $0 / r q$ & س & نيكل \\
\hline$\% / 00$ & ०० & $\% / 0 V$ & $0 / 09$ & $0 / 19$ & $0 / 90$ & سת/ם & $\circ / 14$ & $0 / 14$ & مس \\
\hline O/OY & $0 / 0 Y^{t}$ & $\circ / 09$ & $0 / 19$ & $0 / T_{1}$ & $0 / 19$ & $0 / 1 T$ & $0 / \varphi_{0}$ & $0 / 91$ & روى \\
\hline
\end{tabular}

مىشود. فاكتور غنىشدكى طبق رابطه ( (1) محاسبه مىشود: $\mathrm{EF}=\frac{\mathrm{M}_{\mathrm{x}} / \mathrm{Fe}_{\mathrm{x}}}{\mathrm{M}_{\mathrm{b}} / \mathrm{Fe}_{\mathrm{b}}}$

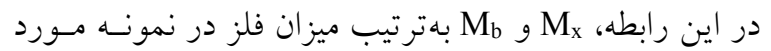

مطالعه و در نمونه استاندارد است (IV). عنصر مرجع مسىتوانـد Fe ، و Al باشد كـه در بسـيارى از مطالعـات از عنصـر آهـن استفاده مىشود (YT). در اين مطالعه نيز از عنصر آهن بهعنـوان عنصر مرجع استفاده شده است. بر اساس شاخص غنىشـدگى،

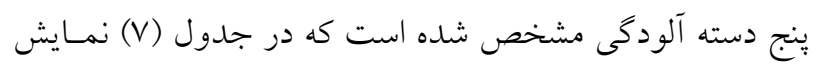

داده شده است (TV) (TV).

محاسبه فاكتور غنى شدكى براى عناصـر مختلـف در منطقـه مورد مطالعه با توجه به جدول (V) بيانكر اين اسـت كـه عنصـر كبالت تهى تا كمى غنى شده، عناصر نيكـل و مسس نسـبتاً غنسى

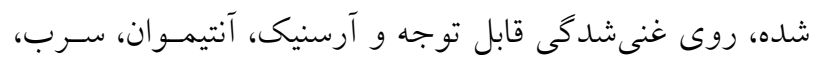
كـادميم و بيسـموت بيشـترين غنسىشـدكى را در منطقـه نشـان مى دهند. در شكل (V))، نقشه هاى بيهنهبندى براساس فاكتور غنى

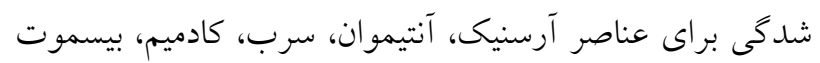

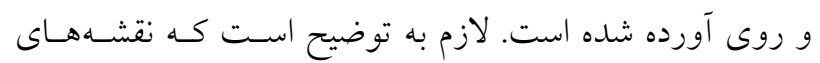
ترسيمى براساس تخمين بيكلسى انجـام شـده بـر روى فـاكتور غنى شدكى است. براى تهيه نقشـههـاى فـاكتور غنسى شـدگى از
براى يافتن منشأ رسـوبات، الخــوى يــر اكنش عناصـر و ارزيـابى زيستمحيطى وضعيت موجـود در يـك منطقـه باشــ (YY). در صورت نبود دسترسى به امكانات لازم، مىتـوان از علـم آنـاليز خوشهاى براى منشأيابى عناصر سنخين در رسوبات استفاده كرد

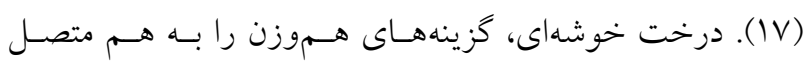
مى كند تا خوشههاى بزرگتر ايجـاد شـود و شـباهت هـاى بـين نمونهها را سنجش و ارزيابى مىكنــ (9ا و YY). نتسايج تحليـل خوشهاى حاكى از اين است كه آرسنيك بـا كـادميم و آنتيمـوان در يك شاخه قرار كرفتـه و سـرب و روى هـم در يـى شـاخه هستند. آرسنيك، كادميم، آنتيموان، سرب و روى يـى گرـروه را

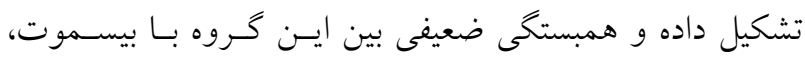
كبالت، مس و نيكل مشاهده مىشـود (شـكل 9). بـا توجسهـ بــ شكل (צ)، نيكل و كبالت در يك گروه مجزا و مس و بيسـموت نيز در گروه ديخر قرار مى گيرند. بهطوركلى، نتايج بهدست آمــه از همبستخى عناصر و تحليل خوشهاى نشان مىدهد كه عناصـر مورد مطالعه از سه منشأ مجزا حاصل شدهاند.

\section{فاكتور غنى شدكى}

فاكتور غنى شـدگى جهـت ارزيـابى آلـودگى خـاك و رسـوبات (افزايش يا كاهش عناصر نسبت به مقدار استاندارد آنها) استفاده 


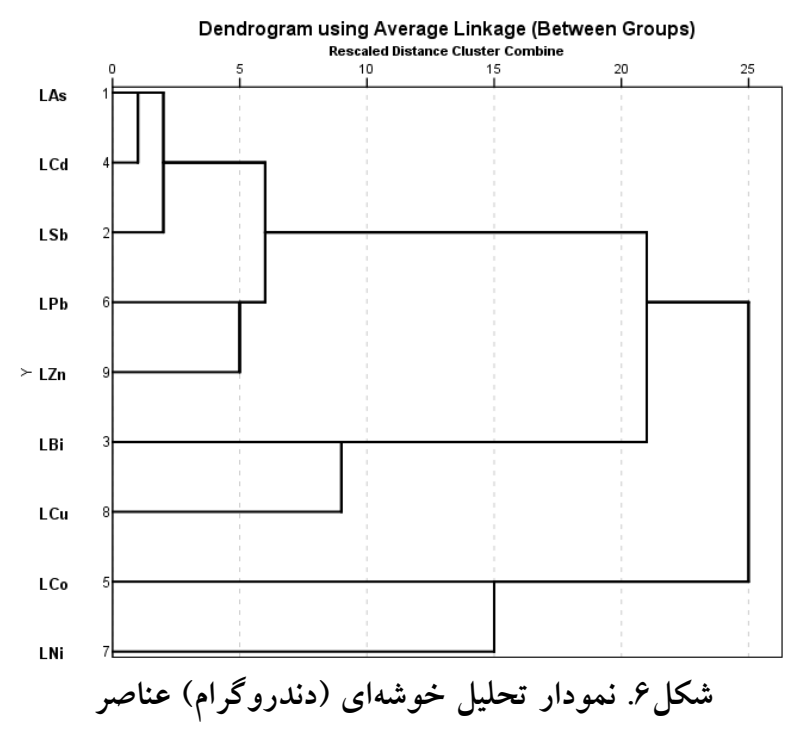

\begin{tabular}{|c|c|}
\hline EF & سطح آلودحىى \\
\hline$<r$ & تهى تا كمى غنى شده \\
\hline$r-Q$ & نسبتاً غنى شده \\
\hline$\Delta-r_{0}$ & غنى شدگى قابل توجه \\
\hline$r_{0-r} r_{0}$ & شديداً غنى شده \\
\hline$r_{0}<$ & بىنهايت غنى شده \\
\hline
\end{tabular}

آنتيموان (شكل V- ب)، منطقه داراى غنىشدگى قابل توجـه تـا

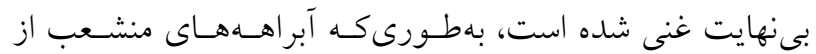

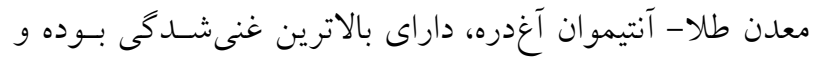

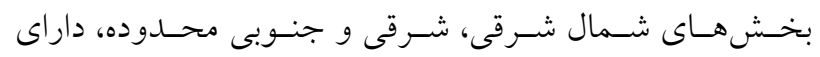

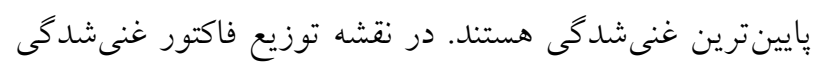

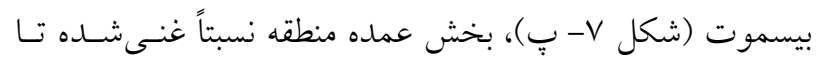

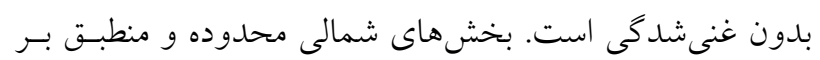

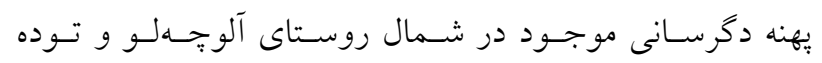

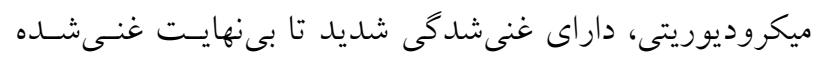

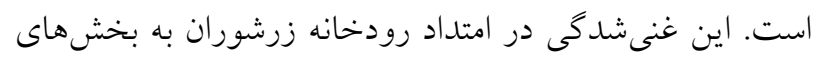
جنوبىتر نيز كشيده شده اسـت. براسـاس نقشـهـ توزيـع فـاكتور

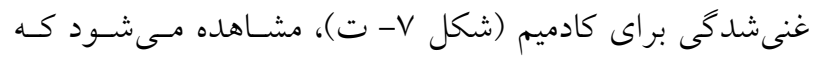

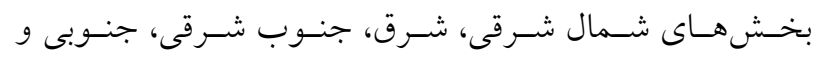

روش ميانيابى IDW استفاده شد. در اين روش، براورد مقــادير

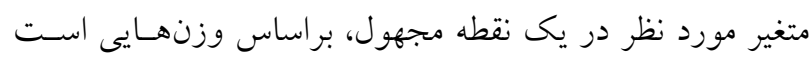

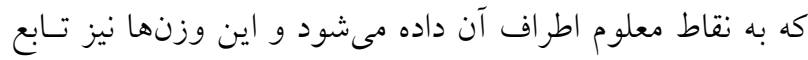

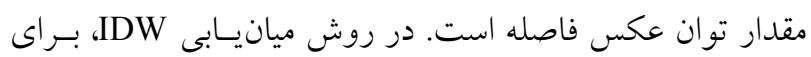

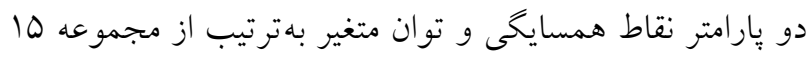

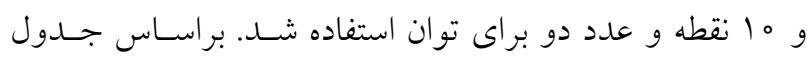

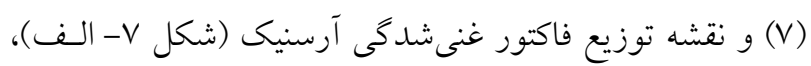

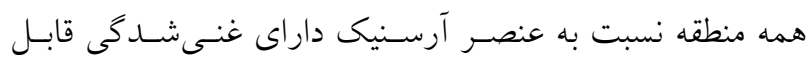

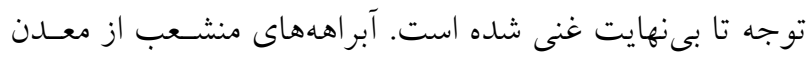

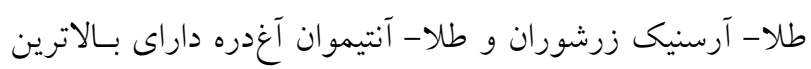
غنى شدكى است. بخششهاى شمالى و شرقى محدوده منطبق بـر

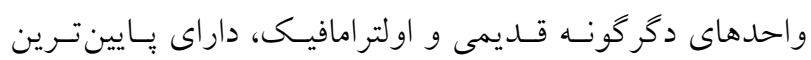

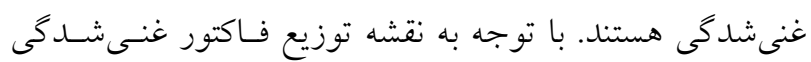



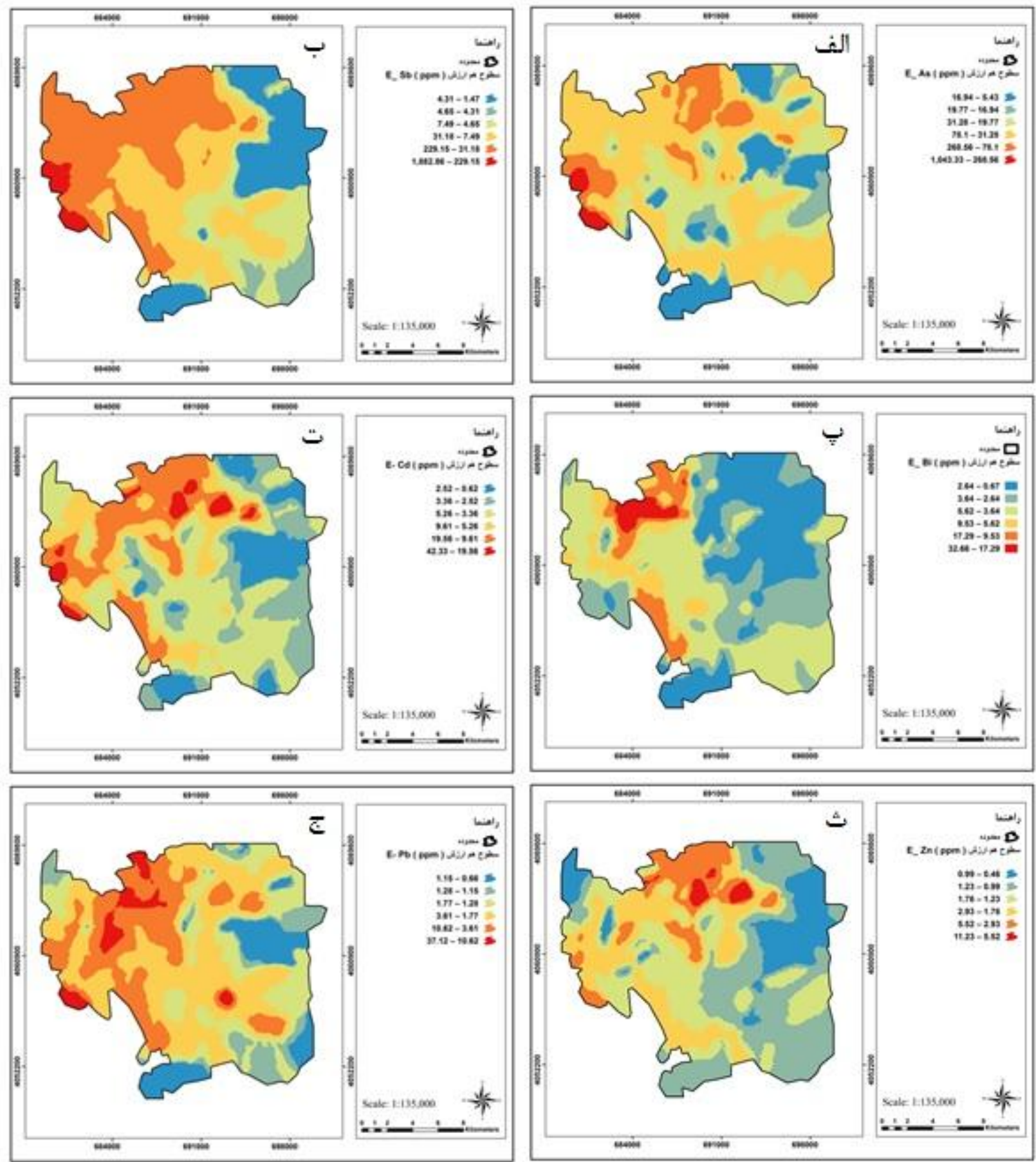

شكل V. نقشه توزيع فاكتور غنىشدگى براى عناصر: الف) آرسنيك، ب) آنتيموان، ب) بيسموت، ت) كادميم، ث) روى و ج) سرب

غنىشدكى در امتداد رودخانه زرشوران به بخشهاى جنوبىتسر

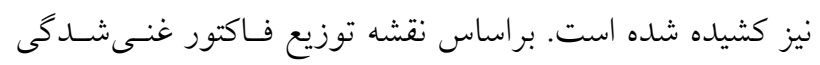

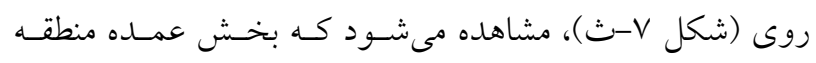

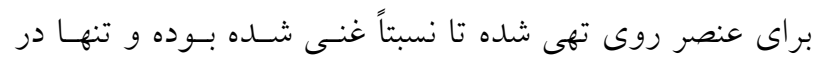

مركزى منطقه مورد مطالعه براى عنصر كادميم نسبتاً غنىشده تـا

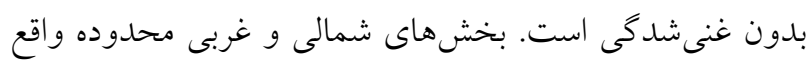

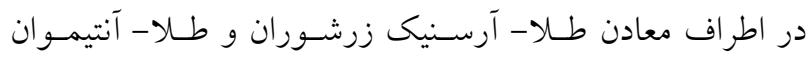
آغدره داراى غنىشدكى شديد تا بىنهايت غنى شده است. ايسن 
دوردست از معدن زرشوران در محيط اثبات شده اسـت كـه بـاــا

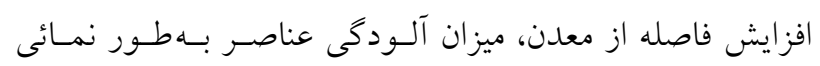

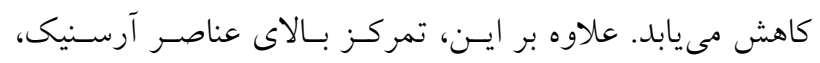

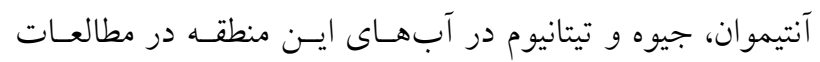
مدبرى و مر (سا) تأييد شده است كه آلودكى مزبور به كانهزايى

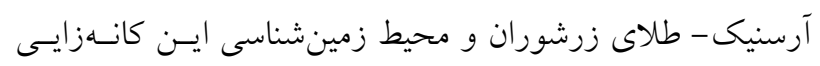

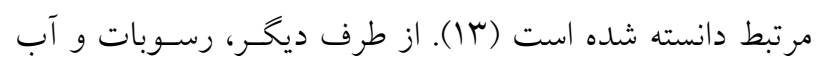
رودخانه شـاخه فرعى آغدره از عناصـر آرسـنيك، آنتيمـوان و جيوه، بهشدت آلوده گزارش شده است (4 أ). نتيجـه مطالعـات انجام شـده توسـط رحسيم سـورى و همكـارن (9)، منشـأ ايسن آلودكى ها را شيل هاى سياه حاوى كانهزايى در معدن آنتيمـوان-

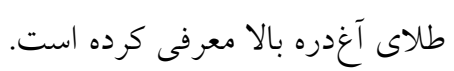
بهطوركلى، تجزيـه و تحليـل هـاى بـهدسـت آمــه از آنـاليز

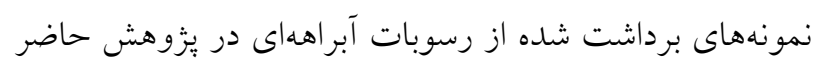

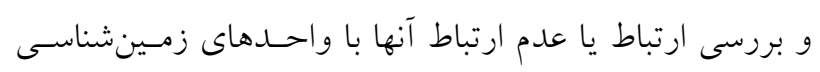

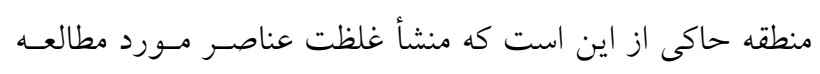

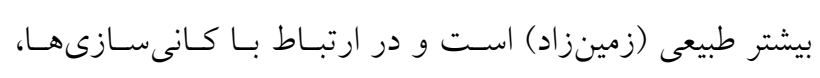
دكرسانى ها و واحدهاى سنكى مستعد تمركزهاى بالاى عناصـر

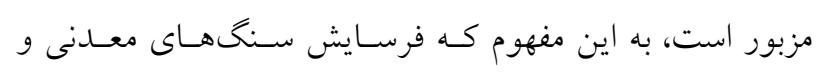

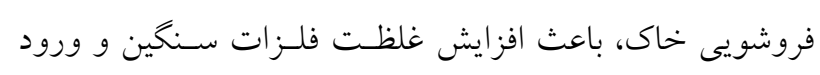
آنها به آبها شده و منجر به كسترش تمركز عناصر ياد شده بـهـ بخشهاى جنوبى منطقه و دور از مراكز كانىسازى گشته است، ليكن بهنظر مىرسد، وجود فعاليتهاى معدنى در معـادن طـلاجآرسنيك زرشوران و طلا- آنتيموان آغدره نيز در افزايش تمركـز فئز عناصر آرسنيك، آنتيموان، سـرب، روى و كـادميم در رسـوبات آبر اهـاى اين منطقه بى تأثير نبوده است.
بخش شـمالى منطقـه و منطبـق بـر كانسهزايسى طـلاله آرسـيكى زرشوران و سنخـهاى اولترامافيـك هسـته طاقـديس زرشـوران، غنىشدگى نسبتاً قابل توجه اين عنصر را شاهد هستيم. در نقشه ترسيمى براى توزيع فاكتور غنىشدگى فلز سرب (شـكل V-ج) مشاهده مىشود كه بخش عمده منطقه براى اين عنصر تهى شده

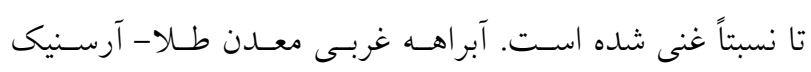

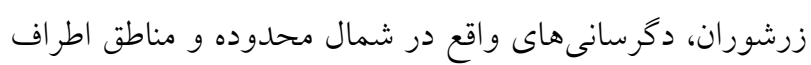

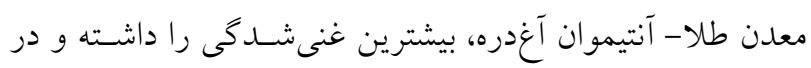

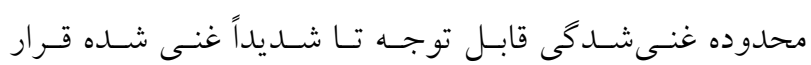

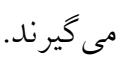

\section{نتيجه كيرى}

با مقايسه مقدار ميـانحين كـل عناصـر در نمونـههــاى رسـوبات

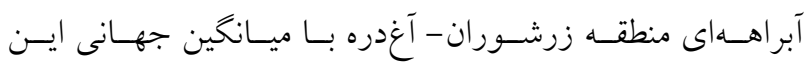
عنصرها، مشخص شد كه غلظت روى، مس، سـرب، آرسـيك،

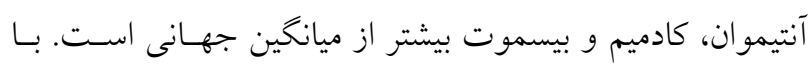

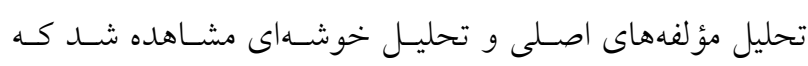

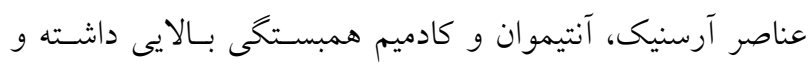

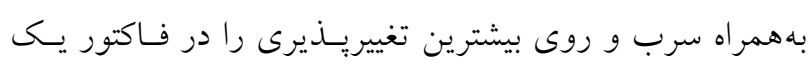

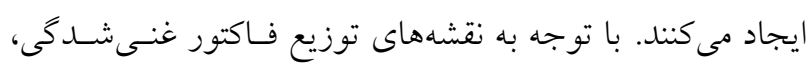
مشخص شد كه قسمت هاى شمالى، شمال غرب و غرب منطقه بيشترين غنى شدكى را بـراى عناصسر مـورد مطالعـه و بـهاويـزّه

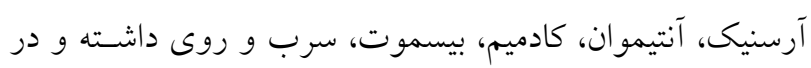
قسمتهاى جنوبى تمركز غير عادى عناصـر مـورد نظـر وجـود

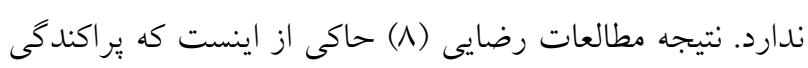

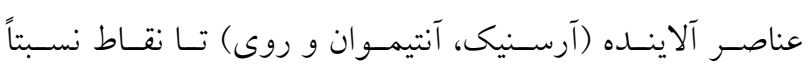

\section{منابع مورد استفاده}

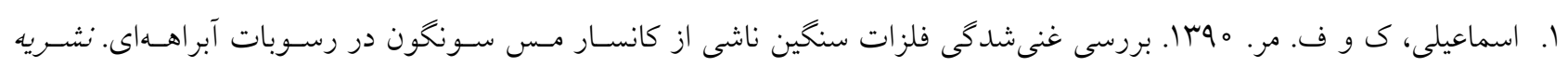

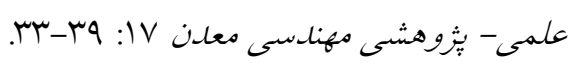

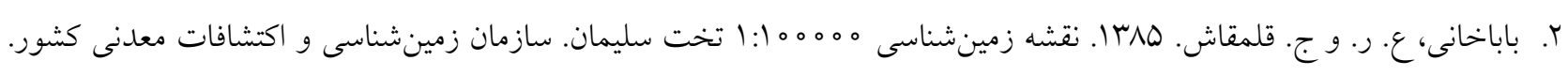


ب. بنى اردلان، س. الوبا. بررسى غلظت و توزيع فلزات سنگين در خاكهاى اطراف معدن زرشوران در شهرستان تكـاب. يايـاننامـه كارشناسى ارشد، كروه علوم محيط زيست، دانشكده علوم، دانشخاه زنجان.

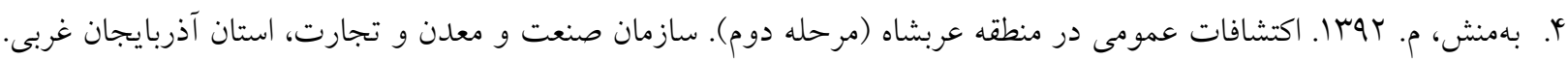

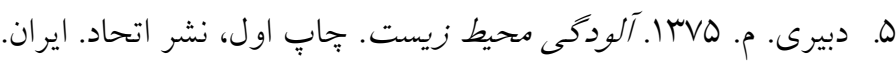

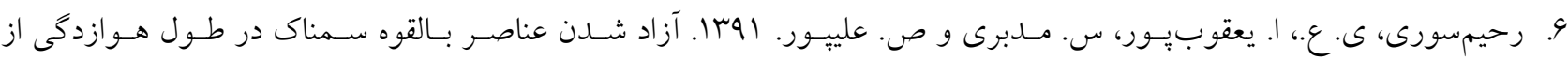

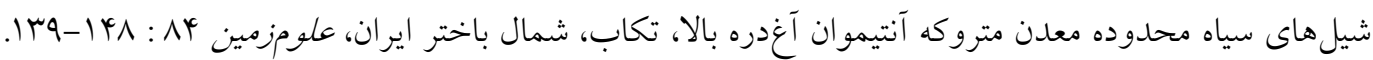

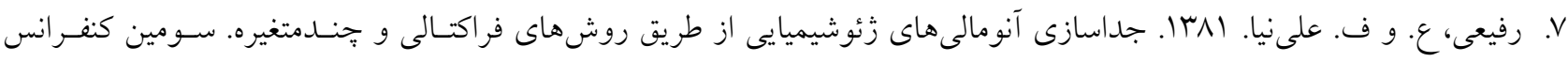
دانشجويى مهندسى معلدن أY-

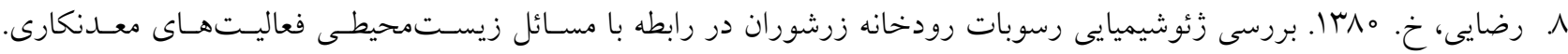
بايانامه كارشناسى ارشد رسوبشناسى و سنخشناسى رسوبى، دانشخاه خوارزمى، تهران.

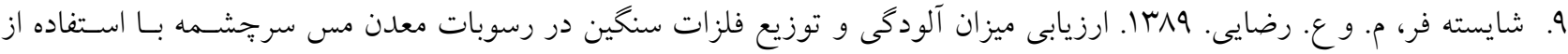

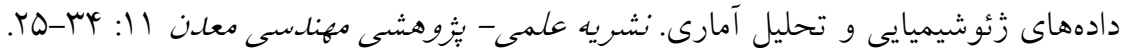
ه ا.شرفى، ك.، س. ا. مظاهرى، ع. ر. عابدى و ق. م. زهانى. rوبا. بررسى غلظت فلزات سنگين در خاكهاى محدوده معدن نيـزهآب (درح). انجمن زمينشناسى مهندسى ايران. هشتمين همايش انجمسن زمسينشناسـى مهندسى و محسيط زيسـت ايسران. دانشـاه فردوسى مشهل. مشهل.

ا ا. شهبازى، ع.، ع. سفيانيان، ن. مير غفارى و م. عين قلايى. اوسا. بررسى آلودگى فلزات سنگين خاك بـا اسـفاده از شـاخصهـاى فاكتور آلودگى، زمين انباشتخى و شاخص جامع فاكتور آلودخى (مطالعـه مـوردى: شهرسـتان نهاونــ). محسيط زيسـت و توسعه

rا. شهدادى. س. و م. مسلميور. •وبا. مطالعه آلودگى رسوبات جنوب شـرق تهـران بـه عناصـر سـمى بـا استفاده از روش تحليـل مؤلفهاى اصلى و تعيين شاخص آلودگى. محيطشناسى 9. 9. rا. مدبرى، س. و ف. مر. rیرا. زمينشيمى زيستمحيطى و نقش كانسار زرشوران در آلـودكى منـابع آب منطقـه تكـاب. هشـتمين همايش انجمن زمين شناسى ايران.

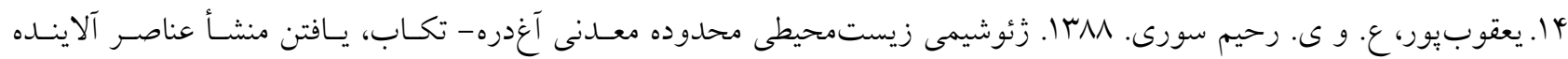
آرسنيك، آنتيموان و جيوه و بررسى تأثير فعاليت معدنكارى و صنايع معدنى در ايجـاد آلـودگى آب، رسـوبات و خــاك منطقـه. كزارش نهايى طرح بزوهشى، سازمان حفاظت محيط زيست.

15. Abrahim, G. M. S. and R. J. Parker, 2008. Assessment of heavy metal enrichment factors and the degree of contamination in marine sediments from Tamaki Estuary, Auckland, New Zealand. Environmental Monitoring and Assessment 136(1-3): 227-238.

16. Anazawa, K., Y. Kaida, Y. Shinomura, T. Tomiyasu and H. Sakamoto. 2004. Heavy-metal distribution in river waters and sediments around a" firefly village", Shikoku, Japan: Application of multivariate analysis. Analytical Sciences 20(1): 79-84.

17. Devis, J. C. 1986. Statistics and data analysis in Geology. Wiley International, New York.

18. Hollert, H. 2003. A new sediment contact assay to assess particulate-bound pollutants using Zebrafish (Danio rerio) embryos. Journal of Soils and Sediments 3(3): 197-207.

19. Loska, K. and D. Wiechula. 2003. Application of principal component analysis for the estimation of source heavy metal contamination in surface sediments from Rybnik Reservoir. Chemosphere 51: 723-733

20. MacFarlane, G. R. and M. D. Burchett. 2000. Cellular distribution of $\mathrm{Cu}, \mathrm{Pb}$ and $\mathrm{Zn}$ in the Grey Mangrove Avicennia marina (Forsk.). Aquatic Botany 68(1): 45-59. 
21. Mucha, A. P., M. T. S. D. Vasconcelos and A. A. Bordalo. 2003. Macrobenthic community in the Doura estuary: relations with trace metals and natural sediment characteristics. Environmental Pollution 121: 169-180.

22. Nguyen, H. L., M .Leermakers, M. Elskens, F. De Ridder, T. H. Doan and W. Baeyens. 2005. Correlations, partitioning and bioaccumulation of heavy metals between different compartments of Lake Balaton. Science of the Total Environment 341(1-3): 211-226.

23. Rafiee, A. 2005. Separating geochemical anomalies in stream sediment media by applying combination of fractal concentration-area model and multivariate analysis. In: Proceeding of the $20^{\text {th }}$ World Mining Congress, Iran. PP: 461-470.

24. Shajan, K. P. 2001. Geochemistry of Bottom sediments from a River- Estuary- Shelf Mixing Zone on the tropical Southwest Coast of India. Bulletin of Geological Survey of Japan 52(8): 371- 382.

25. Wedepohl, K. H. 1995. The composition of the continental crust. Geochimica et Cosmochimica Acta 59(7): 12171232.

26. Yalcin, M. G., R. Battaloglu and S. Ilhan. 2007. Heavy metal sources in Sultan Marsh and its neighborhood, Kayseri, Turkey. Environmental Geology 53: 399-415.

27. Yongming, H. 2006. Multivariate analysis of heavy metal contamination in urban dusts of Xi'an, Central China, Science of the Total Environment 355(1): 176-186. 


\title{
Investigation of Environmental Pollution in Stream Sediments for Heavy Metals at Zarshuran- Aghdarreh Area (North of Takab, Iran)
}

\author{
S. P. Mousavi ${ }^{1}$, M. A. Asghar Mokhtari², Y. Khosravi ${ }^{* *}$, A. Rafiee ${ }^{3}$ and R. Hosseinzadeh ${ }^{4}$
}

(Received: September 5-2016; Accepted: July 15-2017)

\begin{abstract}
In this study, the distribution of heavy metals pollution including arsenic, antimony, nickel, copper, cadmium, cobalt, bismuth, lead and zinc in the stream sediments of Zarshuran- Aghdarreh area was investigated by using statistical techniques and the geometric integration of each sample basin. For this purpose, the degree of pollution in 154 stream sediment samples was analyzed and the distribution maps for enrichment factors were prepared by using a combination technique, pixel estimation, and statistical and geostatistical methods. The results of calculating the enrichment factors indicated that the higher enrichment was related to arsenic, antimony, bismuth, cadmium and lead. Furthermore, the concentration of zinc, copper, lead, arsenic, antimony, cadmium and bismuth in the stream sediment samples was higher than the global average. Application of the principal component analysis on the data led to the recognition of 9 main components for the dataset; the first 5 were components with eigen values greater than 1 and a cumulative percentage more than $85 \%$. Arsenic, antimony, cadmium, lead and zinc in the first component, cobalt in the second component, bismuth in the third component, copper in the fourth component and nickel in the fifth component had the highest values.
\end{abstract}

Keywords: Heavy metals, Environmental pollution, Enrichment factor, Principal component analysis, Zarshuran, Aghdarreh, Takab

1. Department of Environmental Sciences, Faculty of Sciences, University of Zanjan, Zanjan, Iran.

2. Department of Geology, Faculty of Sciences, University of Zanjan, Zanjan, Iran.

3. Department of Mining Engineering, Faculty of Engineering, University of Zanjan, Zanjan, Iran.

4. Geological Survey and Mineral Exploration of Iran, Tehran, Iran.

*: Corresponding Author, Email: khosravi@znu.ac.ir 